\title{
Gastric clearance of serum albumin in normal man and in certain gastroduodenal disorders
}

\section{A. BRASSINNE}

From the Division of Gastroenterology, Department of Medicine, Institute of Medicine, University of Liège, Bavière Hospital, Liège, Belgium

SUMMARY Serum albumin gastric loss was estimated from the measurement of non-dialysable radioactivity of the gastric juice after intravenous injection of radioiodinated serum albumin (RISA). Immunochemical quantitation of serum albumin was performed in some of the samples.

In the control group, the mean gastric clearance of albumin was $1.71 \mathrm{ml}$ per hour with a range of 0.41 to $4.41 \mathrm{ml}$ per hour. This represented a gastric loss of 1.9 gram of albumin per day and $11 \%$ of the daily degradation of albumin. There was no significant change in the gastric albumin loss after stimulating the gastric secretion. No significant difference in the gastric albumin leakage was found between normal subjects and patients with gastric or duodenal ulcer.

In pernicious anaemia albumin loss into the stomach was greater (mean: $3.72 \mathrm{ml}$ per hour; SD $1.52 \mathrm{ml}$ ) than in the normal group and accounted for the greater albumin fractional catabolic rate. This fact had never been proved before. In both patients with giant rugae of the gastric mucosa the gastric clearance of serum albumin was also increased.

It is concluded first that albumin is not secreted by the chief and parietal cells of the mucosa and probably passes through the gastric wall between the cells of the mucosa, perhaps during the exfoliation of the surface epithelial cells, and secondly that the stomach is one of the sites of serum albumin breakdown, a fact that supports the view that the gastrointestinal tract plays a major role in the catabolism of serum albumin.

In spite of the well known presence of serum albumin and other plasma proteins in neutral or neutralized gastric juice, few quantitative estimations of the intragastric protein loss have been made so far and they concerned only pathological cases (Citrin, Sterling, and Halsted, 1957; Jeffries, Holman, and Sleisenger, 1962).

In normal man, Wetterfors, Gullberg, Liljedahl, Plantin, Birke, and Olhagen (1960) were the first to measure quantitatively the gastric leakage of serum albumin in nine subjects only three of whom could be considered normal. They estimated the gastric loss to be one tenth or less of the total serum albumin catabolism. However the method used was severely criticized by Waldmann (1966) and Kerr, Dubois, and Holt (1967). Moreover so far no study has been attempted of the possible relationship between gastric leakage of albumin and gastric secretion, which occurs after every meal with the attendant increase in gastric blood flow.

The aims of the present study were primarily to Received for publication 15 January 1974. measure as accurately as possible, in normal as well as in pathological subjects, the passage of albumin from the plasma to the gastric juice in the basal secretory state and during stimulated secretion. Our second purpose was to quantitate the part of the stomach loss in the total breakdown of serumalbumin.

Evidence is given that gastric leakage of albumin is not related to the rate of mucosal secretion and that the stomach is responsible for about $11 \%$ of total serum albumin catabolism.

\section{Material and Methods}

\section{CHOICE OF SUBJECTS}

The control group consisted of 41 normal volunteers, 35 males and six females, 21 to 29 years old. In all controls there was no history of gastric disease and the serum protein level, electrophoretic pattern, and blood cell counts were normal.

The pathological group included seven patients with duodenal ulcer, three with gastric ulcer, seven with pernicious anaemia, one case of giant hyper- 
trophic gastritis, and one case with reversibly enlarged gastric folds and hypoproteinaemia.

\section{DETERMINATION OF GASTRIC ACID SECRETION RATE}

Before measuring the serum albumin turnover, basal (one-hour) and stimulated (two-hour) gastric acid secretion was measured in every case by the method of Lambling, Badoz-Lambling, Lebouc, and Bernier (1955).

The gastric acid secretion was stimulated by 0.5 $\mathrm{mg}$ histamine in all pathological cases and in control group 1 (14 subjects). In control group 2 (seven cases), $100 \mathrm{mg}$ Histalog was injected subcutaneously, in control group 3 (seven cases) insulin 0.15 unit per $\mathrm{kg}$ intravenously, and in group 4 (seven cases) pentagastrin $6 \mu \mathrm{g}$ per $\mathrm{kg}$ subcutaneously. In control groups 5 (three cases) and 6 (three cases) gastric secretion was not stimulated. In group 5 an intragastric perfusion of a $20 \mathrm{~g} / 100 \mathrm{ml}$ glucose solution was performed.

\section{MEASUREMENT OF SERUM ALBUMIN}

METABOLISM

After intravenous injection of 100 microcuries of 131I radioiodinated serum albumin (RISA ${ }^{1}$ ), the albumin fractional catabolic rate was determined in all subjects according to the method of Pearson, Veall, and Vetter (1958). The absolute catabolic rate was calculated from the fractional catabolic rate and total circulating albumin. The serum protein level was determined by the biuret method (Gornall, Bardawill, and David, 1949) and the serum albumin concentration from cellulose acetate electrophoresis (Demaret, 1966). Thyroid uptake of 131I-iodine released by RISA breakdown was blocked by administration of Lugol two days before and during the whole study.

\section{MEASUREMENT OF ALBUMIN LEAKAGE INTO THE STOMACH}

The method has been described and discussed in detail elsewhere (Brassinne, 1972). The measurements were usually performed seven or eight days after the intravenous injection of 131I-RISA. Seven control subjects and four patients with pernicious anaemia had two measurements at intervals of six or seven days. Two tubes were swallowed after an overnight fast and positioned under fluoroscopy, the first at the lowest point of the stomach of the sitting patient and the second $15 \mathrm{~cm}$ above. Contamination with saliva was avoided by aspiration. Before collecting the gastric juice the stomach was carefully washed out with physiological saline.

RISA from the CEN, Mol, Belgium.
Gastric juice was aspirated continuously through the first tube with a syringe and through the second one a $0.15 \mathrm{M}$ sodium bicarbonate solution was injected continuously into the gastric lumen in order to neutralize gastric acidity and prevent serum albumin proteolysis. The rate of perfusion ( 1 to $5 \mathrm{ml}$ per minute) was adjusted so as to reach neutralization of acidity which was checked periodically with indicator paper throughout the test. Five microcuries of ${ }^{125} \mathrm{I}$ radioiodinated serum albumin was added to the bicarbonate solution perfused into the stomach. This allowed the calculation of net volumes of secreted gastric juice (Johnston and McCraw, 1958) and determination of pyloric loss and of unavoidable digestion of serum albumin (Brassinne, 1972). The extent of this correction amounts to about $20 \%$ of the gastric clearance. Microscopic haemorrhage caused by gastric tubing was measured and subtracted by labelling the red blood cells with 15 to 20 microcuries of ${ }^{59} \mathrm{Fe}$-citrate injected intravenously 10 days previously. Contamination by duodenal secretions was assessed by noting bile discoloration of the aspirates. This was not present in any specimens from which gastric clearance of serum albumin was calculated. Each test lasted for four hours: two hours before and two hours after stimulation of gastric secretion. The stimulus was the same as the one used for the measurement of gastric acid output.

In each hourly sample of gastric juice, free iodine radioactivity was eliminated by dialysis against tap water for 12 hours at $4^{\circ} \mathrm{C}$ : this process proved to be more efficient than trichloracetic acid precipitation of proteins (Brassinne, 1972). Protein-bound radioactivity was concentrated by dialysis against a hypertonic $30 \mathrm{~g} / 100 \mathrm{ml}$ solution of polyethyleneglycol.

All radioactivity measurements were made in a well-type scintillation counter with a two-channel pulse-height analyzer, thus allowing an easy separation of the ${ }^{131} \mathrm{I},{ }^{125} \mathrm{I}$, and ${ }^{59} \mathrm{Fe}$ counts.

\section{IMMUNOCHEMICAL QUANTITATION OF} SERUM ALBUMIN

In order to check the results observed with RISA, serum albumin was measured by the single radial immunodiffusion method of Mancini, Carbonara, and Heremans (1965) on neutralized gastric juices in vivo and on the sera of the same subjects.

We verified the absence of unspecific precipitate between non-immune rabbit serum and neutralized human gastric juice and that there was no interference by this fluid with the immunological quantitation of serum albumin. Gastric loss of serum albumin was estimated by the immunodiffusion method in 27 control subjects, in five patients with duodenal ulcer, and in two with pernicious anaemia. 


\section{CALCULATIONS}

The non-dialysable ${ }^{131}$ I radioactivity recuperated in the stomach during one hour, corrected for pyloric loss, unavoidable digestion and microscopic haemorrhage, was divided by the plasma radioactivity (cpm per ml) which is almost entirely bound to serum albumin (Berson, Yalow, Schreiber, and Post, 1953; Lewallen, Berman, and Rall, 1959; Wetterfors et al, 1960), thus giving the gastric clearance of serum albumin expressed in $\mathrm{ml}$ per hour. The same calculation was done on the basis of immunochemical data.

The results were analysed statistically by the $t$ test of Student for comparison of the mean values for normal and pathological groups, and by a two-way analysis of variance for comparison of the gastric clearances of albumin before and after stimulation of gastric secretion.

\section{Results}

IN NORMAL MAN

Figure 1 shows the means and standard deviations of acid output in milliequivalents per hour and of albumin gastric clearance in millilitres per hour before and after stimulation of gastric secretion with $0.5 \mathrm{mg}$ histamine subcutaneously. It is obvious that

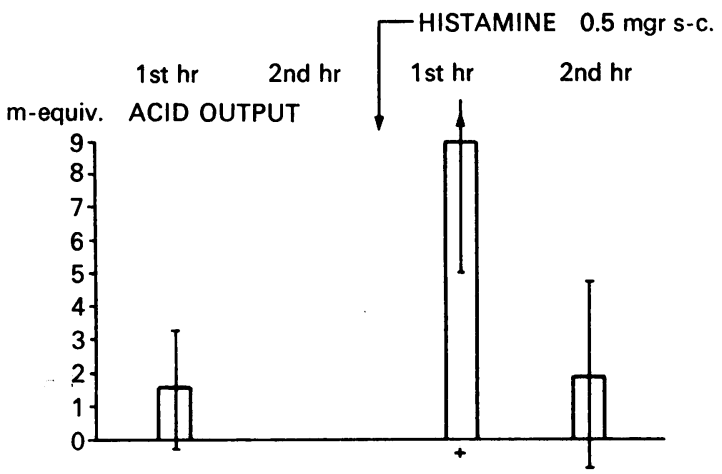

GASTRIC CLEARANCE OF ALBUMIN



Fig 1 Control group 1 (14 subjects). At the top half: means (columns) and standard deviations (vertical bars) of acid output in m-equiv per hour before and after subcutaneous injection of $0.5 \mathrm{mg}$ of histamine. Below, gastric clearance of serum albumin in $\mathrm{ml}$ per hour before and after histamine injection at the same dose.

+ corresponds to statistically different values $(\mathrm{P}<0.05)$. there was no correlation between acid output and albumin leakage into the stomach. Similar results for albumin gastric clearance were obtained after the injection of Histalog, insulin, or pentagastrin. Also, the intragastric perfusion of hypertonic glucose solution did not modify the albumin gastric clearance.

For the 41 normal subjects, gastric clearance of serum albumin at the second hour was significantly lower than at the first hour with the respective means $1.71 \mathrm{ml}$ and $2.07 \mathrm{ml}$ per hour $(\mathrm{f}=12.118 ; \mathrm{P}<0.01)$. The second hour gastric clearance of albumin varied from 0.41 to $4.41 \mathrm{ml}$ per hour. The histogram (fig 2) of the 41 normal subjects showed an asymmetrical distribution $\left.\left(\mathrm{g}_{1}{ }^{1}\right)=0.8893 ; \mathrm{P}<0.01\right)$, thus requiring a square root transformation of the data for



Fig 2 Histogram of the gastric clearance of serum albumin in 41 normal subjects.

normalization $\left(\mathrm{g}_{1}=0.21 ; \mathrm{p}>0.05\right)$. The albumin gastric clearances corresponding to the mean of the square roots and this mean \pm 2 SD were respectively $1.61,3.63$, and $0.4 \mathrm{ml}$ per hour. Statistical treatment without square root transformation of the data did not change the conclusions.

As shown in the table, the serum albumin loss into the stomach amounted on an average to $11.3 \%$ of its catabolism in normal man.

\section{IN GASTRODUODENAL DISEASE}

In the patients with duodenal ulcer gastric clearance and catabolism of serum albumin were not significantly different from the control group (fig 3 ).

The same was true with the gastric ulcer patients whose albumin gastric clearances were $1 \cdot 31,1 \cdot 71$, and $1.8 \mathrm{ml}$ per hour.

${ }^{1}$ Test of symmetry according to Snedecor (1956). 
Gastric

clearance

of albumin

(ml/hr)



$(g / 24 \mathrm{hr})$
Serum

concentration

of albumin

$(g / 100 \mathrm{ml})$
\% I.V. Pool Catabolism

Percentage degraded

in the stomach

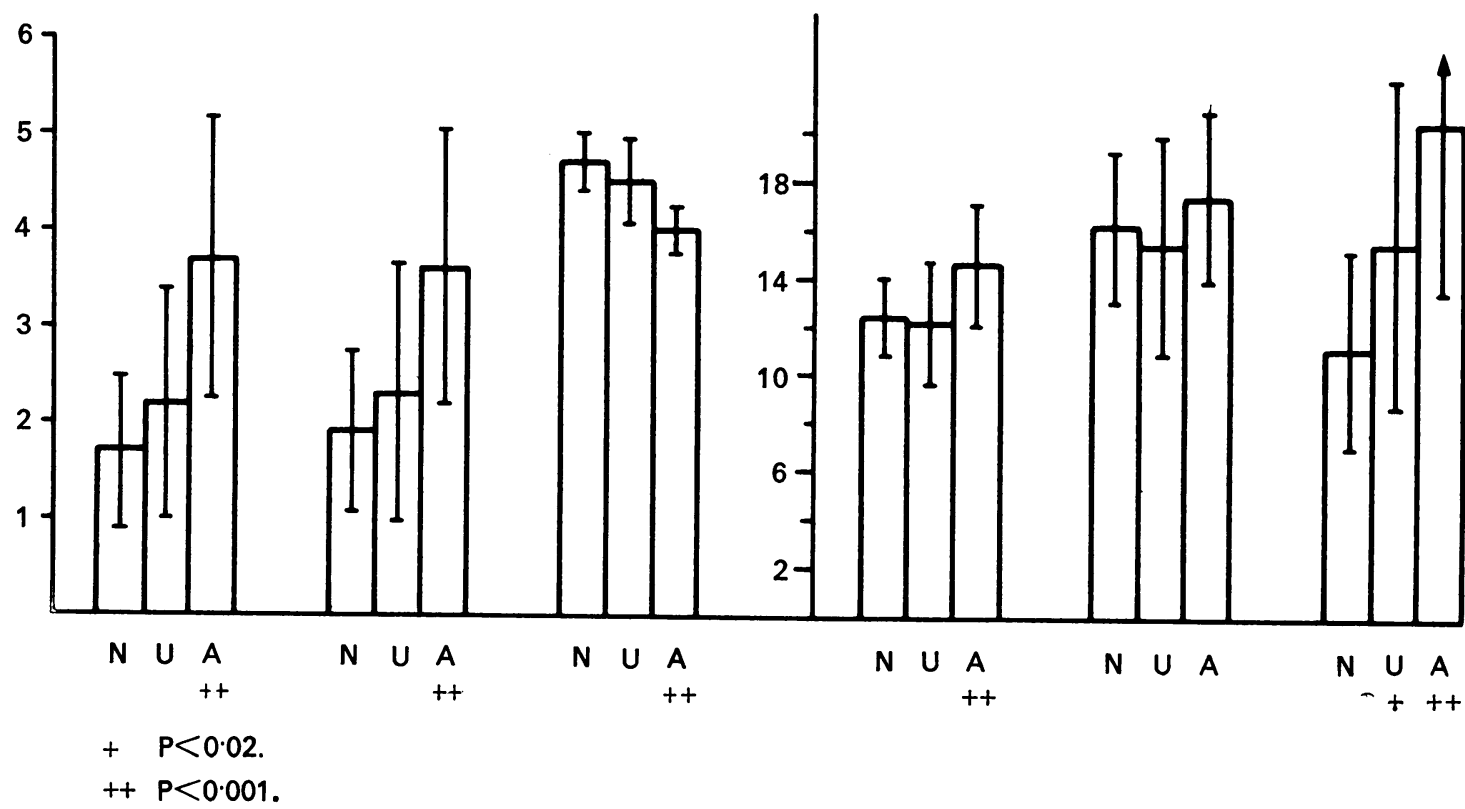

Fig 3 Means (columns) and standard deviations (vertical bars) of the gastric clearance of serum albumin (ml per hour), albumin loss into the stomach ( $\mathrm{g}$ per day), albumin concentration in serum $(\mathrm{g} / 100 \mathrm{ml})$, fractional catabolic rate as a percentage of the intravascular pool, absolute catabolic rate in grams per day, and percentage breakdown in the stomach in control subjects $(N)$, in seven patients with duodenal ulcer $(U)$, and in seven patients with pernicious anaemia $(A)$.

In pernicious anaemia (fig 3), the gastric clearance of serum albumin was significantly greater than in the normal group (respective means and standard deviations: $3.72 \pm 1.52$ and $1.71 \pm 0.83 \mathrm{ml}$ per hour). It accounted for the greater fractional catabolic rate of serum albumin in this disease: $14.48 \pm 2.51$ instead of $12.40 \pm 1.69 \%$ of intravascular albumin. It resulted in a lower level of albumin in serum: $40.69 \pm 2.57$ instead of $46.96 \pm$ $3.26 \mathrm{~g}$ per litre. In this disease the loss of albumin into the stomach amounted on an average to $20.6 \%$ of the total catabolism.

In the case of giant hypertrophic gastritis (Ménétrier's disease), albumin gastric clearance was 6.22 $\mathrm{ml}$ per hour corresponding to $27 \%$ of the total metabolic clearance. It fell to $2.59 \mathrm{ml}$ or $17 \%$ of the metabolic clearance after subtotal gastrectomy. The diagnosis of Ménétrier's disease was confirmed by histological findings.

In a woman with radiological giant rugae of the stomach, histamine-fast achlorhydria and hypoproteinaemia, the gastric clearance of serum albumin was $5.6 \mathrm{ml}$ per hour. The enlarged folds of the gastric mucosa and the hypoproteinaemia disappeared in a few weeks. There was no histological analysis.

\section{IMMUNOCHEMICAL STUDIES}

The gastric clearance of serum albumin as determined by the single radial immunodiffusion method was similar to the one measured with RISA. The mean and standard deviation for the 27 normal subjects was $1.94 \pm 0.88 \mathrm{ml}$ per hour.

In 16 normal subjects and five patients with duodenal ulcer, the correlation coefficient between both methods applied simultaneously was $\mathbf{0 . 7 8 9 6}$ for 43 basal samples $(P<0.001)$ and 0.5320 for 40 samples after stimulation $(P<0.001)$. The correlation between both methods is considerably better for 12 one-hour samples of gastric juice from 


\begin{tabular}{lcc}
\hline & Mean & Standard Deviation \\
\hline Albumin gastric clearance (ml per hour) & 1.71 & 0.83 \\
Albumin gastric loss (g per day) & 1.90 & 0.92 \\
Catabolism of albumin (g per day) & 16.28 & 3.18 \\
Percentage degraded in the stomach & 11.33 & 4.24 \\
\hline
\end{tabular}

Table Gastric loss and catabolism of serum albumin in 41 normal subjects

two pernicious anaemia patients $(r=0.9827)$. This very good correlation results from the complete lack of proteolytic activity of these gastric juices.

\section{Discussion}

In the clearance calculation it is assumed that the specific activity of albumin is the same in serum and in gastric juice, and that the non-dialysable ${ }^{131}$ I radioactivity of the gastric juice is due to or derived directly from 131I-labelled albumin. The former hypothesis is highly probable since equilibrium between the intravascular and extravascular albumin specific activity is reached at the time of clearance measurement (Pearson, Veall, and Vetter, 1958). The latter hypothesis needs further consideration. First of all, we can exclude an adsorption of radioactive iodide secreted by the stomach on the mucoproteins of gastric juice (Brassinne, 1972). Moreover radioactive iodine is not significantly used again for protein synthesis provided that the thyroid has been blocked beforehand with iodide (Pearson et al, 1958; McFarlane, 1957). Thirdly protein-bound radioactivity of gastric juice after intravenous injection of RISA is localized to serum albumin on electrophoresis (Wetterfors et al, 1960; Berson et al, 1953; Lewallen et al, 1959). Finally the good correlation we obtained between radioactive and immunological methods is evidence that the nondialysable ${ }^{131}$ I of the gastric juice is mostly bound to serum albumin molecules.

Microscopic haemorrhage due to the intubation procedure was low, about $10 \%$ of the albumin gastric clearance, and transient protein loss without haemorrhage (Waldmann, 1966; Kerr et al, 1967) could not be detected from the comparison of the fractional catabolic rate on the day of intubation and of the fractional catabolic rate on the day preceding intubation (mean difference $0.336 ; \mathrm{t}=$ 1.254 for paired values). However critics might object that the duration of each experiment (four hours) is relatively short. In three patients not included in the present series a nasogastric tube was left in the stomach for seven days with intragastric perfusion of bicarbonate during the night, and removed for seven days. This prolonged intubation did not alter the fractional catabolic rate of albumin. Thus it is reasonable to disregard the above objection.
Our results indicate that the albumin loss into the stomach does not depend on the secretion of either hydrochloric acid or pepsin as well since the drugs used stimulate pepsin secretion in man. Independently from us, Vidon and Bernier (1971), using ${ }^{51}$ chromium labelled albumin, found no increase in the gastric clearance of albumin after histamine stimulation. Similarly, Brooks, Isenberg, and Goldstein (1970) noticed no change in gastric loss of albumin after stimulation in a case of hypertrophic hypersecretory gastritis. In dogs with a Heidenhain pouch, Davenport (1966) observed no modification of the ${ }^{51} \mathrm{Cr}$-albumin loss into the pouch after stimulation of the secretion by histamine or bethanechol.

The albumin gastric clearances reported here are higher than those published by Wetterfors (1965) who found a mean gastric clearance of albumin of $1.1 \mathrm{ml}$ per hour with a range of 0.71 to $2.2 \mathrm{ml}$ per hour. This may be due to differences in the number of subjects and, more likely, in the methods. In particular Wetterfors neutralized gastric acidity with phosphate buffer which is less efficient than bicarbonate (Brassinne, 1972) and made no correction for pyloric loss and unavoidable digestion. On the other hand, Vidon and Bernier (1971) using ${ }^{51} \mathrm{Cr}$ albumin found a mean gastric clearance of albumin of 2 to $3 \mathrm{ml}$ per hour.

According to the present results, the gastric loss of albumin amounts to 1.9 gram per day on an average (see table). This result is to be compared with the estimation of Makhlouf, Moore, and Blum (1968) using a completely different approach. These authors studied in human gastric juice the relationships between the concentrations of $\mathrm{Na}$ or acid on the one hand and the concentrations of non-peptic proteins on the other. From their calculations they conclude that the average leakage of total plasma proteins across the stomach wall is approximately 2.5 grams per day. Since we found a mean gastric loss of 1.9 gram per day for albumin alone, the estimation of Makhlouf and coworkers concurs with, and consequently confirms, our own results. Gastric leakage of the other plasma proteins remains to be determined.

These findings are in agreement with those of the Scandinavian authors (Wetterfors et al, 1960; Wetterfors, 1964; Wetterfors, 1965; Glenert, Jarnum, and Riemer, 1962; Jarnum, 1963) whose results indicate that slightly more than half of the total 
albumin degradation takes place in the gastrointestinal tract. However this problem is controversial since the whole digestive tract clearance of serum proteins as measured from the radioactivity in the stools after the intravenous injection of ${ }^{51}$ Cr-albumin (Waldmann, 1966; Waldmann, Wochner, and Strober, 1969) or ${ }^{51}$ chromium chloride (Van Tongeren and Majoor, 1966) amounts to 30 or at most $60 \mathrm{ml}$ per day, and Vidon and Bernier (1971) and we find the same values for the stomach alone. This discrepancy remains unexplained since chromium is not absorbed in the digestive tract. We think, however, that direct measurement performed with a method eliminating all sources of error, as the one described here, should give more reliable results.

Our findings in the pathological cases confirm the absence of a relationship between gastric secretion and serum albumin loss. This is particularly obvious in pernicious anaemia since, in this disease, the chief and parietal cells are lacking in the gastric mucosa and yet albumin leakage is increased. Therefore atrophic gastritis of pernicious anaemia may be considered to be a protein-losing gastropathy. This fact had never been demonstrated on a quantitative output basis.

Our findings show that serum albumin is not secreted by the parietal and chief cells of the mucosa. Moreover albumin has never been detected in the mucous cells of the gastrointestinal tract (Holtzer and Holtzer, 1960; Brooks and Dobbins, 1971). Thus, it may be inferred by exclusion that serum albumin passes across the mucosa between the cells. In atrophic gastritis of pernicious anaemia this passage is increased together with the relative turnover of the surface epithelial cells (Croft, Pollock, and Coghill, 1966). It is suggested that albumin leakage into the stomach occurs during the extrusion of these cells from the mucosa. This hypothesis has been put forward to explain the protein-losing enteropathy in the active coeliac syndrome, a very similar condition of mucosal atrophy with a higher than normal loss of epithelial cells (Da Costa, Croft, and Creamer, 1971).

\section{References}

Berson, S. A., Yalow, R. S., Schreiber, S. S., and Post, J. (1953). Tracer experiments with $I^{181}$ labeled human serum albumin: distribution and degradation studies. J. clin. Invest., 32, 746-768.

Brassinne, A. (1972). La clearance gastrique de la sérumalbumine chez l'homme. Thesis, University of Liège, Belgium.

Brooks, S. G., and Dobbins, W. O. (1971). I-125 labelled albumin distribution in the intestinal tract of guinea pigs. (Abstr.) Gastroenterology, 60, 645.

Brooks, A. M., Isenberg, J., and Goldstein, H. (1970). Giant thickening of the gastric mucosa with acid hypersecretion and proteinlosing gastropathy. Gastroenterology, 58, 73-79.
Citrin, Y., Sterling, K., and Halsted, J. A. (1957). The mechanism of hypoproteinemia associated with giant hypertrophy of the gastric mucosa. New Engl. J. Med., 257, 906-912.

Croft, D. N., Pollock, D. J., and Coghill, N. F. (1966). Cell loss from human gastric mucosa measured by the estimation of deoxyribonucleic acid (DNA) in gastric washings. Gut, 7, 333-343.

Da Costa, L. R., Croft, D. N., and Creamer, B. (1971). Protein loss and cell loss from the small-intestinal mucosa. Gut, 12, 179-183.

Davenport, H. W. (1966). Fluid produced by the gastric mucosa during damage by acetic and salicylic acids. Gastroenterology, 50, $487-499$.

Demaret, M. (1966). Étude d'une ultramicrométhode d'électrophorèse sur acétate de cellulose. Ann. Biol. clin., 24, 369-382.

Glenert, J., Jarnum, S., and Riemer, S. (1962). The albumin transfer from blood to gastro-intestinal tract in dogs. Acta chir. scand., 124, 63-74.

Gornall, A. G., Bardawill, C. J., and David, M. M. (1949). Determination of serum proteins by means of the biuret reaction. J. biol. Chem., 177, 751-766.

Holtzer, H., and Holtzer, S. (1960). The in vitro uptake of fluorescein labelled plasma protein. C.R. Lab. Carlsberg, 31, 373.

Jarnum, S. (1963). Protein Losing Gastroenterology. Blackwell, Oxford.

Jeffries, G. H., Holman, H. R., and Sleisenger, M. H. (1962). Plasma proteins and the gastrointestinal tract. New Engl. J. Med., 266, 652-660.

Johnston, D. H., and McCraw, B. H. (1958). Gastric analysis: evaluation of collection techniques. Gastroenterology, 35, 512-516.

Kerr, R. M., Dubois, J. J., and Holt, P. R. (1967). Use of ${ }^{125} \mathrm{I}$ - and ${ }^{51} \mathrm{Cr}$ labelled albumin for the measurement of gastrointestinal and total albumin catabolism. J. clin. Invest., 46, 2064-2082.

Lambling, A., Badoz-Lambling, J., Lebouc, R., and Bernier, J. J. (1955). Contribution à l'étude de la physiopathologie de la sécretion gastrique. II. Interprétation des renseignements fournis par la titrimétrie des sucs gastriques. C.R. Soc. Biol. (Paris), 149, 1953-1959.

Lewallen, C. G., Berman, M., and Rall, J. E. (1959). Studies of iodoalbumin metabolism. I. A mathematical approach to the kinetics. J. clin. Invest., 38, 66-87.

McFarlane, A.S. (1957). The behaviour of ${ }^{131}$ l labeled plasma proteins in vivo. Ann. N.Y. Acad. Sci., 70, 19-25.

Makhlouf, G. M., Moore, E. W., and Blum, A. L. (1968). Models for the 'secretion' of pepsin and other proteins by the human stomach. Gastroenterology, 55, 457-464.

Mancini, G., Carbonara, A. O., Heremans, J. F. (1965). Immunochemical quantitation of antigens by single radial immunodiffusion. Immunochemistry, 2, 235-254.

Pearson, J. D., Veall, N., and Vetter, H. (1958). A practical method for plasma albumin turnover studies. Radioaktive Isotope in Klinik und Forschung, 3, 290-297.

Snedecor, G. W. (1956). Statistical Methods Applied to Experiments in Agriculture and Biology. Iowa State University Press, Ames, Iowa.

Van Tongeren, J. H. M., and Majoor, C. L. H. (1966). Demonstration of protein losing gastroenteropathy. The disappearance rate of ${ }^{81} \mathrm{Cr}$ from plasma and the binding of ${ }^{51} \mathrm{Cr}$ to different serum proteins. Clin. chim. Acta, 14, 31-41.

Vidon, N., and Bernier, J. J. (1971). Détermination par la sérum albumine marquée au ${ }^{\text {si }} \mathrm{Cr}$ des pertes d'albumine plasmatique dans l'estomac chez l'homme. Arch. Mal. Appar. dig., 60, Suppl. 2, 153-168.

Waldmann, T. A. (1966). Protein-losing enteropathy. Gastroenterology, $50,422-443$.

Waldmann, T. A., Wochner, R. D., and Strober, W. (1969). The role of the gastrointestinal tract in plasma protein metabolism. Amer. J. Med., 46, 275-285.

Wetterfors, J. (1965). Albumin: investigations into the metabolism, distribution and transfer of albumin under normal and certain pathological conditions, with special reference to the gastrointestinal tract: a clinical and experimental study. Acta med. scand., Suppl. 430.

Wetterfors, J. (1964). The normal passage of serum-albumin into the gastro-intestinal tract and its role in the catabolism of albumin: an experimental study in dogs. Acta med. scand., 176, 787-799.

Wetterfors, J., Gullberg, R., Liljedahl, S. O., Plantin, S. O., Birke, G., and Olhagen, B. (1960). Role of the stomach and small intestine in albumin breakdown. Acta med. scand., 168, 347-363. 